\title{
EFFECT OF WOOD SAW DUST AND CHOPPED JUTE FIBER ON THE TENSILE PROPERTIES OF EPOXY BASED POLYMER COMPOSITE
}

\author{
M.S. HAQUE* and M.A. ISLAM \\ Department of Materials and Metallurgical Engineering, \\ Bangladesh University of Engineering and Technology (BUET), Dhaka-1000, Bangladesh
}

\begin{abstract}
:
Polymer composites play a good role in various engineering applications because of their good combination of various properties such as unbeatable light weight, relatively high strength, ease of fabrication, corrosion resistance, high impact strength, design flexibility, dimensional stability, non-conductive properties, etc. So, polymer composites have attracted big attention from world-wide researchers. Epoxy based composite are largely used in load bearing application such as aerospace and automobile industries due to their good mechanical properties and corrosion resistance. In this research work, epoxy-based composites were developed by adding 5\% wood saw dusts or 2 mm size chopped jute fibers. The jute fibers and saw dusts were added to gain some special property such as biodegradability. The developed composites were then characterized by tensile tests. Experimental results revealed that $5 \%$ saw dusts additions have no significant effect on the tensile strength of epoxy-based polymer composites. However, chopped jute fibers have been found to decrease the strength as well as fracture morphology noticeably.
\end{abstract}

Keywords- Epoxy matrix composites, Natural fibers, Wood saw dust, Chopped jute fiber, Tensile property.

\section{Introduction}

From the middle of the $20^{\text {th }}$ century, composite materials have been the most promising and adoptable engineering materials to many advanced applications. Composite materials have attained most of the beneficial properties from a strong bond between the reinforcement and matrix. The matrix helps the composites in their shaping, surface appearance and protection from environment while the reinforcements bear most of the structural loads [1-4].

There are lots of natural materials to be used for reinforcement of polymer-based materials to make composites. Nature abounds in fibrous materials, especially cellulosic types such as cotton, wood, grains, jute, straw, etc. However, only a small number can be used for engineering purposes. Most fibers are slender, flexible and relatively strong. They are elastic in that they stretch when put under tension and then partially or completely return to their original length when the tension is removed [5]. Jute fiber and wood saw dust are widely used all over the world as reinforcement because of not only for their mechanical properties but also for their highly biodegradability as they are considered as $100 \%$ bio-degradable [6].
Also, jute fiber helps to decrease the creep deformation when it is used as reinforcement in polymer composites [7].

In any high-tech structural application where relatively high strength, stiffness, durability and light weight are required, epoxy resins play a very vital role for making the desired components. This is why in aircraft and aerospace applications as well as offshore racing boats, epoxies have been usually used for years [8]. The aim of this research work is to study the effects of jute fibers and wood saw dusts of similar size with identical weight fraction on the tensile strength of their composites.

\section{Experimental Procedure}

\subsection{Materials preparation for compounding molding}

To develop epoxy-based polymer composites, epoxy resin was purchased from the local market and wood saw dusts were collected from local source and then screened to get about $2 \mathrm{~mm}$ size particles (Fig.1a). Long jute fibers were also collected from local market and cut into $\sim 2 \mathrm{~mm}$ size particles (Fig. 1b). 


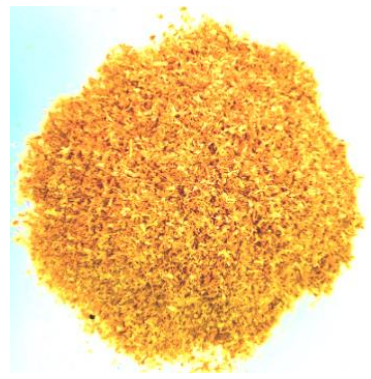

(a)

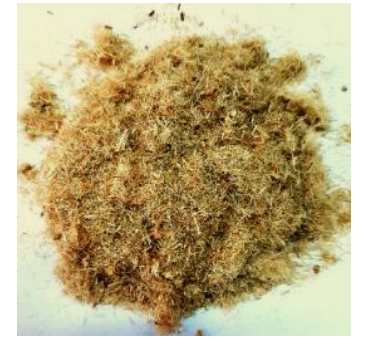

(b)
Figure 1: (a) Wood saw dusts and (b) chopped jute fibers

\subsubsection{Molding of pure epoxy}

Methyl-tetrahydro-phthalic anhydride was used as hardener to cure epoxy resin at room temperature. The ratio of the hardener and epoxy resin was 1: 10 by volume. After adding the hardener into the resin, the mixture was stirred properly to ensure their uniform mixing. Generally, the mixture of the resin and hardener contains dissolved gases. These may form various types of defects such as micro-cracks and voids into the composites that can deteriorate the mechanical properties of the composites. So, the degassing was carried for about 10 minutes. Then the mixture was poured into the mould of required shape for the casting. After casting, it took about 5 to 6 hours to cure the epoxy resin properly.

\subsubsection{Molding of wood saw dust composites}

Before adding the saw dusts into the epoxy resin, they were heated at $100{ }^{\circ} \mathrm{C}$ for about one hour to remove moisture. Then $5 \mathrm{wt} \%$ of saw dusts were mixed with epoxy resin into a beaker properly to get uniform mixing and then hardener (10 vol\% of the resin) also added to the mixture. After vacuum process for about 10 minutes, the mixture was cast into the mould.

\subsubsection{Molding of chopped jute fiber composites}

Same processes were followed for developing composites of chopped jute fiber as mentioned for the wood saw dust composites.

\subsubsection{Preparation of the sample for the tensile tests}

In order to determine the effect of natural fiber on the epoxy-based composites, 5 cast samples of pure epoxy resin, epoxy-based 5 wt $\%$ wood saw dust composites and epoxy-based $5 \mathrm{wt} \%$ chopped jute fiber composites of rectangular shaped sheets (Figs.2a, 2b and $2 \mathrm{c}$ ) were made. Using these cast sheets, tensile samples were prepared shown in Fig.2d.

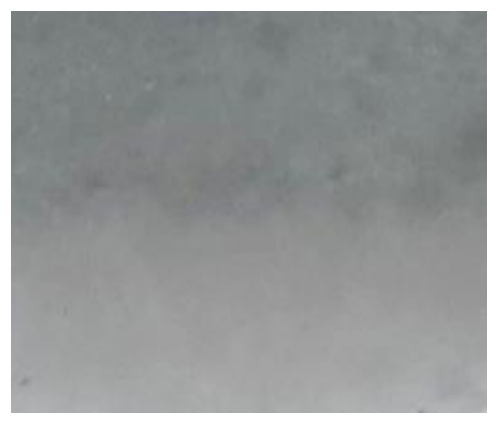

(a)

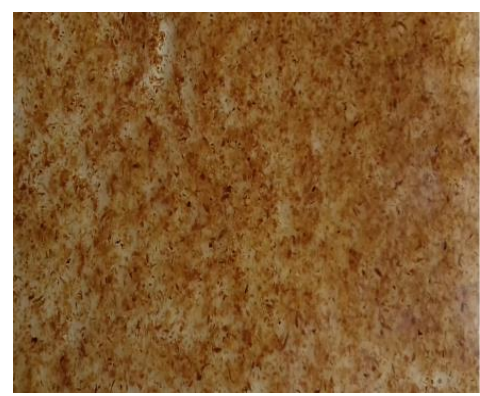

(b)

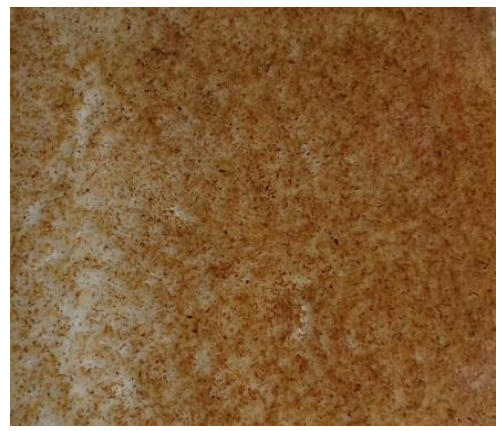

(c)

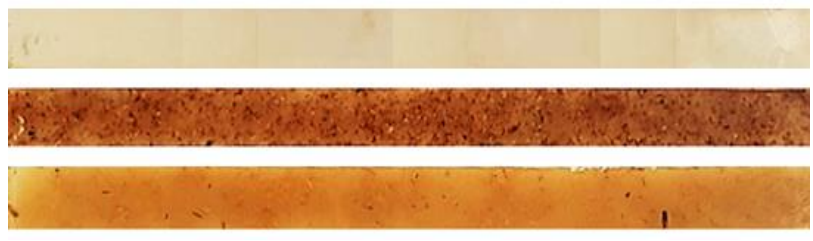

(d)

Figure 2: (a) Cast samples of pure epoxy, (b) epoxy-based saw dust composite, (c) epoxy-based chopped jute fiber composite and (d) tensile test samples. 


\subsection{Tensile Test:}

The rectangular cast samples were cut to make tensile test samples (Fig. 2d) For each group 5 tensile test samples were tested on Universal Testing Machine (Model: Instron 3369 and capacity: $50 \mathrm{kN}$ ). The experimental data are shown in Table 1.

Table 1:

The tensile test results of the epoxy resin and epoxy-based composites.

\begin{tabular}{|c|c|c|c|c|}
\hline $\begin{array}{l}\text { Sample } \\
\text { Name }\end{array}$ & $\begin{array}{c}\text { Sample } \\
\text { No }\end{array}$ & $\begin{array}{l}\text { Stress } \\
\text { (MPA) }\end{array}$ & $\begin{array}{l}\text { Average } \\
\text { Stress } \\
\text { (MPA) }\end{array}$ & $\begin{array}{c}\text { Change of } \\
\text { stress }\end{array}$ \\
\hline \multirow{5}{*}{ Epoxy } & 1 & 18.28 & \multirow{5}{*}{20.6} & \multirow{5}{*}{ Nil } \\
\hline & 2 & 21.2 & & \\
\hline & 3 & 22.27 & & \\
\hline & 4 & 19.24 & & \\
\hline & 5 & 21.92 & & \\
\hline \multirow{5}{*}{$\begin{array}{c}\text { Epoxy } \\
+ \\
\text { Saw } \\
\text { Dust }\end{array}$} & 1 & 20.44 & \multirow{5}{*}{20.4} & \multirow{5}{*}{$\begin{array}{c}0.98 \% \\
\text { decrease }\end{array}$} \\
\hline & 2 & 23.12 & & \\
\hline & 3 & 18.37 & & \\
\hline & 4 & 19.79 & & \\
\hline & 5 & 20.28 & & \\
\hline \multirow{5}{*}{$\begin{array}{c}\text { Epoxy } \\
+ \\
\text { Chopped } \\
\text { Jute } \\
\text { Fiber }\end{array}$} & 1 & 18.56 & \multirow{5}{*}{17.9} & \multirow{5}{*}{$\begin{array}{l}15.08 \% \\
\text { decrease }\end{array}$} \\
\hline & 2 & 17.22 & & \\
\hline & 3 & 18.12 & & \\
\hline & 4 & 18.23 & & \\
\hline & 5 & 17.57 & & \\
\hline
\end{tabular}

\section{Results and Discussion}

From experimental tensile test data presented in Table 1, it is clear that the average tensile strength of the pure epoxy resin is $20.6 \mathrm{MPa}$. The value of tensile strength of the epoxy resin varies from researchers to researchers due to the different sources of the raw materials and experimental variables such as temperature, fraction and types of hardener used, curing time, etc [9-12]. In this experiment, the tensile strength found for the pure epoxy sample was within the range that has been mentioned by different researchers.

\subsection{Mode of tensile failure:}

The stress-strain curve of pure epoxy resin, epoxy based wood saw dust composite and epoxy based chopped jute fiber composite are shown in Fig.3. All the samples failed in the elastic zone (Fig.3) that indicates the all samples of pure epoxy and its composites were brittle in nature. The fracture surfaces of the broken tensile samples are shown in Fig.4. This figure reveals the fracture surfaces to be almost flat and smooth. After fracture, the thickness and width of the tensile test samples remained unchanged. This observation also suggests the brittle mode of fracture behavior of the tensile samples.

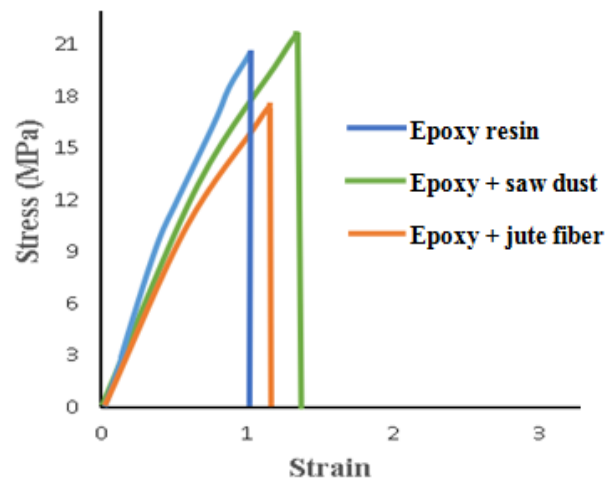

Figure 3: Stress- strain curve for epoxy resin and epoxy based composites.
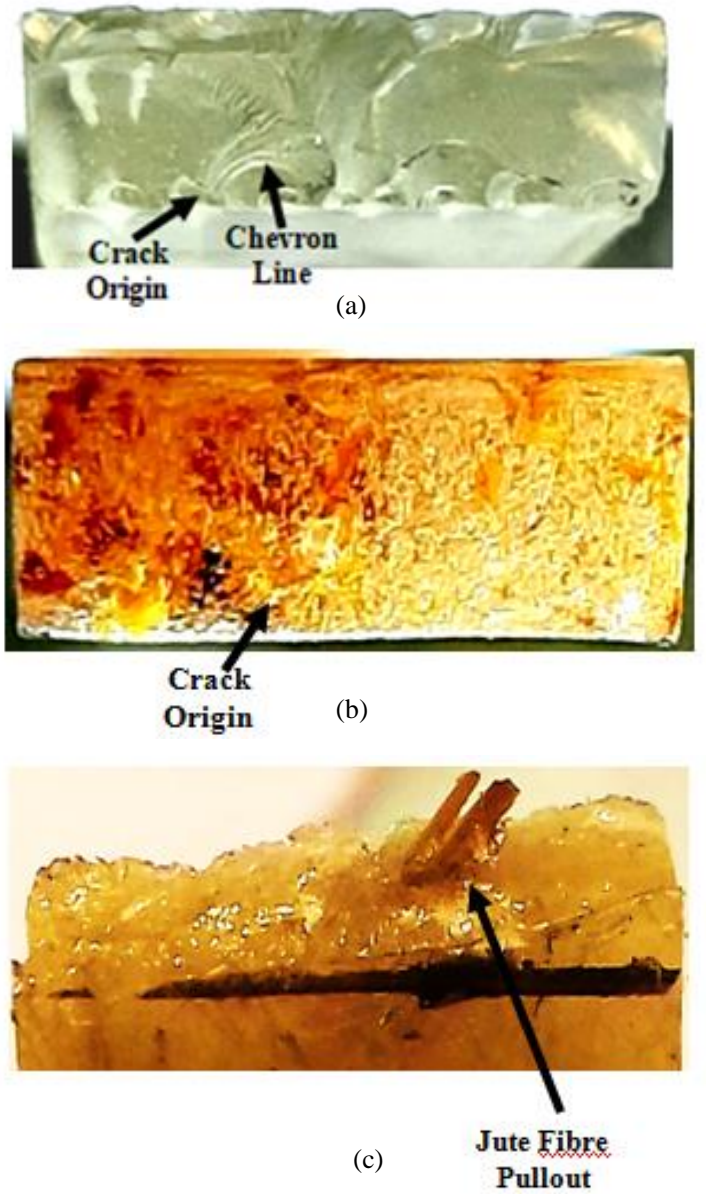

Figure 4: (a) Fracture surface of pure epoxy resin, (b) wood saw dusts composite and (c) chopped jute fibre composite. 


\subsection{Effect of wood saw dust and jute fibers on tensile strength of epoxy resin:}

From Table 1, it is clear that addition of $5 \mathrm{wt} \%$ wood saw dusts did not decrease the tensile strength of the composites to any sensible level. At the same time, saw dust addition did not increase the tensile strength. Moreover, because of spherical shape dust particles, uniform mixing in the matrix was possible, Fig.5a. It has been mentioned that jute fiber is stronger than wood fiber [13-14]. These mean there was enough interfacial bonding between wood saw dusts and surrounding epoxy matrix that could manage the deterioration in tensile strength. However, in this experiment addition of jute fiber decreased the tensile strength of the composites (Table 1). The possible reason behind this decrease in tensile strength is the formation lump of jute fibers. Evidence of lump formation is clear in Fig.5b. This lump formation made the fibre distribution in non-uniform pattern and that interfaces of jute fibres within the lump were not possible to be wetted enough to make strong bonding among them as these fibres naturally remain aligned with each other with a certain level of inter-fibre bonding force. So, at relatively lower level of load fibre pullout (Fig.4c) took place resulting poor tensile strength.

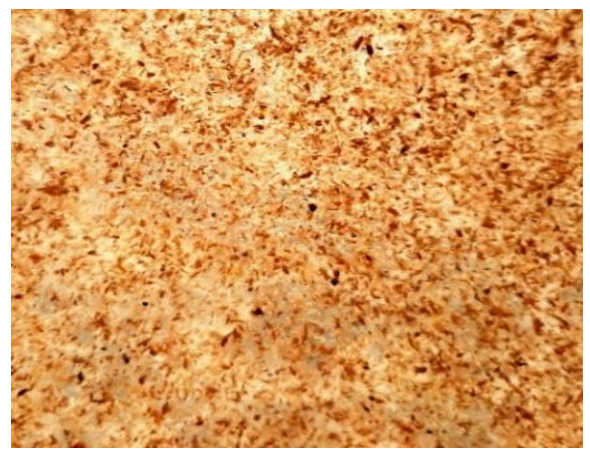

(a)

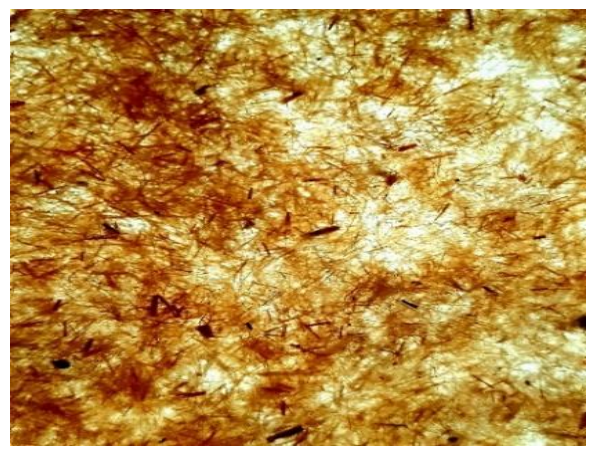

(b)

Figure 5 : Distribution of fibers in the epoxy matrix (a) wood just dust composite and (b) chopped jute fibre composite.
Pure epoxy resin is resistant to degradation in the natural environment because the microorganisms do not have the enzymes to degrade the epoxy resin. But addition of wood saw dust and chopped jute fiber in epoxy resin could influence the biodegradability behavior of the composites. As microorganisms possibly attack the wood saw dust or chopped jute fiber that would help to break down the bonding chain throughout the epoxy matrix [15-16]. This could be also responsible for the degradation of the tensile strength of the composites.

\section{Conclusions}

In this research work initiative has been taken to study the effects of same weight percentage of wood saw dust and jute fibres of similar sizes on the tensile strengths and fracture behaviours of epoxy based polymer composites. After detail experimental work, the following conclusions are made.

i. Addition of around $5 \mathrm{wt} \% 2 \mathrm{~mm}$ size wood saw dust in epoxy polymer does not degrade the tensile strength. However, addition of $5 \mathrm{wt} \%$ of $2 \mathrm{~mm}$ size chopped jute fibres decreases the tensile strength of the base polymer by about $15 \%$.

ii. Lump formation and improper surface wetting of the jute fibres have been thought to be the main reasons for the degradation of the tensile strength of the polymer based jute composite.

iii. Epoxy polymer, wood saw dust composite and chopped jute fibre composite exhibited completely brittle mode of fractures. However, Chevron cracking was dominating in the case of pure epoxy and wood saw dust composites. Whereas, fibre pullout was found to play important role in jute fibre composites.

\section{References}

[1] Ogin, S., Brøndsted, P. and Zangenberg, J. (2016). Composite materials. Modeling Damage, Fatigue and Failure of Composite Materials, pp.3-23.

[2] Vasiliev, V. and Morozov, E. (2018). Introduction. Advanced Mechanics of Composite Materials and Structures, p.xvii-xxv.

[3] Encyclopedia of polymer science and technology H. F Mark edition, john wiley and Sons, New York, 1985

[4] AZoM.com. (2019). Composite Matrix Materials. [online] Available at: https://www.azom.com/article.aspx?ArticleID=9814 [Accessed 21 Aug. 2019]. 
[5] Encyclopedia Britannica. (2019). natural fibre | Definition, Uses, \& Facts. [online] Available at: https://www.britannica.com/topic/natural-fiber [Accessed 21 Aug. 2019].

[6] Aly-Hassan, M. (2015). A new perspective in multifunctional composite materials. Multifunctionality of Polymer Composites, pp.42-67.

[7] Santulli, C. (2017). Creep behaviour of plant fibre composites. Advanced High Strength Natural Fibre Composites in Construction, pp.459-477.

[8] Webcache.googleusercontent.com. (2019). The Advantages of Epoxy Resin versus Polyester in Marine Composite Structures. [online] Available at: https://webcache.googleusercontent.com/search?q=cac he:BaC-xpQBdVsJ:

https://mjmyachts.com/images/stories/pdf/sp\%2520adv antages \%2520of\%2520epoxy\%2520resin.pdf+\&cd=11 $\& \mathrm{hl}=\mathrm{en} \& \mathrm{ct}=\mathrm{clnk} \& \mathrm{gl}=$ bd [Accessed 21 Aug. 2019.

[9] Reis, J. (2012). Effect of temperature on the mechanical properties of polymer mortars. Materials Research, 15(4), pp.645-649.

[10] Saw, S., Purwar, R., Nandy, S., Ghose, J. and Sarkhel, G. (2013). Fabrication, Characterization, and Evaluation of Luffa cylindrica Fiber Reinforced Epoxy Composites. BioResources, 8(4).
[11] NetComposites. (2019). Strength \& Stiffness. [online] Available at: https://netcomposites.com/guide/resinsystems/strength-stiffness/ [Accessed 25 Aug. 2019].

[12] Virk, A., Hall, W. and Summerscales, J. (2009). Tensile properties of jute fibres. Materials Science and Technology, 25(10), pp.1289-1295.

[13] Machado, J., Pereira, F. and Quilhó, T. (2019). Assessment of old timber members: Importance of wood species identification and direct tensile test information. Construction and Building Materials, 207, pp.651-660.

[14] Ogawa, T., Yamaga, O., Osawa, S. and Jinnai, H., 2002. Performance of Biodegradable Polymer Containing Rice Bran as Adhesive and Its Biodegradability. Journal of The Adhesion Society of Japan, 38(11), pp.406-412.

[15] Ramasamy, S., Ismail, H. and Munusamy, Y., 2014. Soil burial, tensile properties, morphology, and biodegradability of (rice husk powder)-filled natural rubber latex foam. Journal of Vinyl and Additive Technology, 21(2), pp.128-133.

CBangladesh Uni. of Engg. \& Tech. 